\title{
ROLA I KOMPETENCJE PREZYDENTA UKRAINY W ZAKRESIE KSZTAŁTOWANIA REŻIMU PRAWNEGO OCHRONY CYBERPRZESTRZENI. ANALIZA TEORETYCZNOPRAWNA REGULACJI PRAWNYCH Z ZAKRESU CYBERBEZPIECZEŃSTWA UKRAINY
}

\author{
Marcin Gołębiowski \\ Wydział Prawa i Administracji \\ Uniwersytet Marii Curie-Skłodowskiej w Lublinie \\ ID ORCID: https://orcid.org/0000-0002-6699-0612 \\ e-mail: marcin.golebiowski@poczta.umcs.lublin.pl
}

\begin{abstract}
Streszczenie: Tematyka artykułu oscyluje wokół zagadnień związanych z kształtowaniem regulacji prawnych dotyczących cyberbezpieczeństwa Ukrainy. W artykule przeprowadzono teoretycznoprawną analizę aktów prawnych, w szczególności Konstytucji Ukrainy z dnia 26 czerwca 1996 r. oraz ustaw i dekretów prezydenta Ukrainy regulujących ochronę obszaru cyberprzestrzeni Ukrainy. Autor przedstawił również rolę prezydenta Ukrainy w zakresie formułowania polityki cyberbezpieczeństwa wraz z wyszczególnieniem konstytucyjnych oraz ustawowych kompetencji głowy państwa w przedmiocie ochrony cyberprzestrzeni.
\end{abstract}

Słowa kluczowe: Ukraina, system prawny, prezydent Ukrainy, Konstytucja Ukrainy, cyberbezpieczeństwo, prawo cyberprzestrzeni

\section{WPROWADZENIE}

Jednym z podstawowych zadań państwa jest ochrona obywateli, ich praw i wolności. Gwarancją sprawnego wypełniania obowiązków przez państwo jest zagwarantowanie ładu konstytucyjnego, w tym jasnego podziału obowiązków spoczywających na władzy w ramach konstytucyjnego systemu organów państwa. Sprawne funkcjonowanie organów państwowych oraz procedur zapewnienia bezpieczeństwa i ochrony podstawowych sfer funkcjonowania obywateli w przestrzeni publicznej, zarówno analogowej, jak i cyfrowej, to jedne z głównych wyzwań stojących przed państwami. Warunkiem koniecznym do zagwarantowania bezpieczeństwa narodowego i międzynarodowego państwa jest zintegro- 
wanie i poszerzenie kompetencji tegoż państwa oraz organów władzy publicznej w zakresie zarządzania przestrzenią cyfrową w szczególności w obszarach prawodawstwa, bezpieczeństwa i obrony, wiedzy i informacji, edukacji, transportu oraz przesyłania i zarządzania danymi. Zadaniem państwa jest więc stworzenie kompleksowych regulacji prawnych obejmujących swoim zakresem zapewnienie bezpieczeństwa, w tym bezpieczeństwa cybernetycznego kraju.

Szczególnym wyzwaniem dla Ukrainy jest nie tylko stworzenie przejrzystych przepisów prawnych regulujących materię cyberprzestrzeni, lecz także przestrzeganie ustanowionych reguł prawnych, zarówno przez organy państwowe, jak i obywateli. Regulacje prawne powinny jednoznacznie określać instytucjonalne uprawnienia poszczególnych organów władzy państwowej odpowiedzialnych za sprawowanie bezpieczeństwa cybernetycznego. Ustrojodawca w art. 102 Konstytucji Ukrainy z dnia 28 czerwca 1996 r. (Konstytucjia Ukrajini, BBP, 1996, nr 30, poz. 141) wyraża expressis verbis, że gwarantem suwerenności państwa, integralności terytorialnej, przestrzegania Konstytucji Ukrainy oraz praw i wolności człowieka i obywatela jest prezydent Ukrainy. Tak ukształtowane w Konstytucji Ukrainy funkcje ustrojowe oddziałują na konstytucyjne kompetencje prezydenta Ukrainy wyrażone w art. 106, które odnoszą się do jego obowiązku zapewnienia gwarancji niepodległości państwa, bezpieczeństwa narodowego i prawnej ciągłości państwa. Ustrojodawca ukraiński nie zdecydował się jednak na wyszczególnienie dwuaspektowości bezpieczeństwa narodowego Ukrainy [Stec 2014: 106] w ujęciu zewnętrznym i wewnętrznym. W artykule autor dokona teoretycznoprawnej analizy aktów prawnych regulujących kwestie cyberbezpieczeństwa i próby oceny roli i kompetencji prezydenta Ukrainy w zakresie kształtowania regulacji prawnych obejmujących sferę cyberprzestrzeni w celu zapewnienia bezpieczeństwa cybernetycznego Ukrainy. Celem artykułu jest także wykazanie, że konstytucyjnie zagwarantowane uprawnienia prezydenta Ukrainy w zakresie bezpieczeństwa i obronności państwa silnie oddziałują na proces stanowienia prawa w zakresie cyberbezpieczeństwa jako elementu krajowego systemu bezpieczeństwa narodowego Ukrainy.

W ocenie autora kształtowanie ukraińskich przepisów prawnych regulujących cyberprzestrzeń jest determinowane dwoma podstawowymi czynnikami. Pierwszy odnosi się do trwającego konfliktu zbrojnego we wschodniej części Ukrainy, a drugi jest związany z aspiracjami Ukrainy do przystąpienia do sojuszu NATO. W pracy autor dokona próby wykazania, jak te dwa czynniki wpłynęły na kształt porządku prawnego $\mathrm{w}$ zakresie cyberbezpieczeństwa, $\mathrm{i}$ jaką rolę $\mathrm{w}$ procesie tworzenia i przestrzegania prawa w cyberprzestrzeni pełni prezydent Ukrainy oraz podległe mu konstytucyjnie organy władzy państwowej.

W pracy zostaną przeanalizowane obowiązujące w Ukrainie akty prawne regulujące materię cyberprzestrzeni. Opracowanie może więc stanowić źródło wiedzy dla badaczy systemów bezpieczeństwa narodowego, cyberprzestrzeni, ale również systemów rządów w Ukrainie. Potencjalna wartość poznawcza niniejszego artykułu wiąże się również z aktualnym procesem kształtowania porządku 
prawnego w Ukrainie w zakresie regulowania sfery cyberprzestrzeni oraz przekształceń zachodzących w systemie ustrojowym i prawnym Ukrainy wynikającym ze zmian konstytucyjnych zapoczątkowanych w 2014 roku.

\section{PODSTAWOWE REGULACJE PRAWNE}

Pojęcie cyberbezpieczeństwa na gruncie prawa ukraińskiego jest określeniem stosunkowo nowym. Rada Najwyższa 7 września 2005 r. ratyfikowała, a 15 września 2005 r. prezydent Ukrainy podpisał ustawę o ratyfikacji Konwencji o cyberprzestępczości (Zakon Ukrajiny pro Ratyfikaciju Konwencjii pro Kiberzloczynnisti, BBP, 2006, Nr 5-6, poz. 71). Konwencja ta odnosi się do zagrożeń, jakie mogą wystąpić w cyberprzestrzeni, i zawiera rekomendacje dla państw obejmujących sposoby przeciwdziałania zagrożeniom cybernetycznym mającym negatywny wpływ na społeczeństwo informacyjne [Piskorska 2009: 201].

Ukraina po wydarzeniach z 2014 r., które skutkowały niekonstytucyjnym odsunięciem z urzędu prezydenta Wiktora Janukowicza oraz zmianą, a właściwie przywróceniem zmian konstytucyjnych w 2014 r., zmaga się z wewnętrznymi oraz zewnętrznymi zagrożeniami, bezpośrednio oddziałującymi na sferę bezpieczeństwa narodowego. Słabość regulacji prawnych z zakresu cyberbezpieczeństwa państwa skutkowała niepodejmowaniem należytych działań prawnych mających na celu ochronę obywateli, instytucji i agencji państwowych oraz sektora prywatnego. Dodatkowo spory polityczne wynikające z braku regulacji prawnych dotyczących jasnego podziału kompetencji między organami władzy powodowały brak możliwości efektywnego i realnego wdrażania do systemu prawnego Ukrainy standardów europejskich, pozwalających na integrację państwa z Unią Europejską [Tymkiv 2009: 223].

Jednym z takich zadań priorytetowych było wprowadzenie ramowych przepisów prawnych regulujących obszar cyberprzestrzeni. Proces kompleksowej regulacji prawnej dotyczącej sfery cyberprzestrzeni rozpoczął się w Ukrainie w 2016 r. [Semeniy i in. 2018: 99]. Podstawowym aktem normatywnym (w ujęciu chronologicznym) regulującym ten obszar jest Strategia bezpieczeństwa cybernetycznego Ukrainy, wprowadzona dekretem prezydenta Ukrainy z 15 marca 2016 r. (Ukaz Prezydenta Ukraijny pro riszennja Rady Nacionalnoii Bezpeky i oborony Ukraiiny).

Celem Strategii bezpieczeństwa cybernetycznego Ukrainy (dalej - Strategia Cyberbezpieczeństwa) jest stworzenie warunków dla bezpiecznego funkcjonowania cyberprzestrzeni oraz jej wykorzystanie na rzecz osób fizycznych, społeczeństwa i państwa. Strategia wyznacza i identyfikuje podstawowe zagrożenia oraz określa priorytety i kierunki bezpieczeństwa cybernetycznego Ukrainy. Głównym zadaniem Strategii, według prawodawcy, jest stworzenie Krajowego Systemu Bezpieczeństwa Cybernetycznego Ukrainy. Organem wyznaczonym do koordynowania działań związanych z realizacją postanowień Strategii jest Rada 
Bezpieczeństwa Narodowego i Obrony Ukrainy, jako organ odpowiedzialny za sprawy bezpieczeństwa narodowego i obrony przy prezydencie Ukrainy.

Dokonując analizy postanowień Strategii, należy uznać, że jednym z podstawowych czynników determinujących powstanie Krajowego Systemu Bezpieczeństwa Cybernetycznego jest agresja Federacji Rosyjskiej, mająca wpływ na bezpieczeństwo Ukrainy, zarówno w aspekcie zewnętrznym, jak i wewnętrznym. Zidentyfikowanie zagrożeń bezpieczeństwa cybernetycznego Ukrainy ma na celu między innymi ochronę wszystkich obszarów funkcjonowania państwa i jego obywateli przed pośrednimi lub bezpośrednimi działaniami służb lub osób związanych z Federacją Rosyjską. Przeciwwagą dla wskazanych zagrożeń są określone w pkt. 4 Strategii priorytety i kierunki bezpieczeństwa cybernetycznego Ukrainy. Jednym z podstawowych zadań tam wskazanych jest prowadzenie polityki państwa ukierunkowanej na stworzenie i harmonizację krajowych ram prawnych związanych z cyberbezpieczeństwem z normami i standardami UE i NATO. Zdaniem autora, tak skonstruowane postanowienia aktu normatywnego o znaczeniu strategicznym dla Ukrainy świadczą o odejściu od polityki „,wielowektorowości” [Leszczyński 2014: 54] oraz potwierdzają aspiracje i dążenia Ukrainy do przystąpienia do NATO oraz sprzyjają zacieśnieniu stosunków z Unią Europejską.

Jednym z pierwszych aktów normatywnych wydanych na podstawie Strategii Cyberbezpieczeństwa jest dekret Prezydenta Ukrainy z 7 czerwca 2016 r. o Narodowym Centrum Koordynacji Cyberbezpieczeństwa (Ukaz Prezydenta Ukraijny Nr 242/2016 pro Nacjonalnyii Koordynaciiinyj Centr Kiberbezpeky), dalej zwanym Centrum Cyberbezpieczeństwa. Centrum stanowi organ roboczy Rady Bezpieczeństwa Narodowego i Obrony Ukrainy. Do jego głównych zadań należy analiza: stanu cyberbezpieczeństwa, wyników przeglądu krajowego systemu bezpieczeństwa cybernetycznego, stanu gotowości podmiotów cyberbezpieczeństwa do przeciwdziałania zagrożeniom cybernetycznym, stanu wdrażania przepisów dotyczących cyberbezpieczeństwa, danych dotyczących incydentów cybernetycznych w odniesieniu do państwowych zasobów informacyjnych w systemach informacyjnych i telekomunikacyjnych. W ramach swojej działalności Centrum prognozuje i identyfikuje potencjalne i faktyczne zagrożenia w obszarze cyberbezpieczeństwa w Ukrainie.

Kolejnym etapem procesu ramowego uregulowania cyberprzestrzeni na gruncie prawa ukraińskiego było przyjęcie ustawy z 5 października 2017 r. o podstawowych zasadach zapewnienia bezpieczeństwa cybernetycznego Ukrainy (Zakon Ukraijny pro osnowni zasady zabezpeczennja kiberbezpeczennja kiberbezpeky, BBP, 2017, Nr 45, poz. 403), zwanej dalej ustawą o cyberbezpieczeństwie. Zgodnie z przyjętą preambułą, ustawa ta określa prawne i organizacyjne podstawy dla zapewnienia ochrony życiowych interesów człowieka, obywatela, społeczeństwa oraz narodowych interesów Ukrainy w cyberprzestrzeni, główne cele, kierunki i zasady polityki państwa w dziedzinie cyberbezpieczeństwa, kompetencje organów państwowych, przedsiębiorstw, instytucji, organizacji, osób i obywateli w tej dziedzinie oraz główne zasady koordynacji pracy tych podmiotów związanych 
z zapewnieniem cyberbezpieczeństwa. Ustawa o cyberbezpieczeństwie określa zakres podmiotowy i przedmiotowy bezpieczeństwa cybernetycznego oraz zasady funkcjonowania Krajowego Systemu Bezpieczeństwa Cybernetycznego Ukrainy. Ustawodawca przyjął także w ustawie definicję legalną cyberbezpieczeństwa, rozumianego jako ochrona życiowych interesów człowieka i obywatela, społeczeństwa i państwa podczas korzystania z cyberprzestrzeni, zapewniająca zrównoważony rozwój społeczeństwa informacyjnego i cyfrowego środowiska komunikacyjnego oraz szybkie wykrywanie, zapobieganie i neutralizację rzeczywistych i potencjalnych zagrożeń bezpieczeństwa narodowego Ukrainy w cyberprzestrzeni.

Zagadnienia związane z ochroną cyberprzestrzeni i cyberbezpieczeństwem stanowią również zakres przedmiotowy ustawy z dnia 21 czerwca 2018 r. o bezpieczeństwie narodowym Ukrainy (Zakon Ukraijny pro nacjonalny bezpeky Ukraijiny, Oficijinyj Wisnyk Ukraijiny, 2018 r., Nr 55, stor. 51, poz. 1903). Ustawa ta reguluje zasady bezpieczeństwa narodowego i obronnego, cele i podstawowe zasady polityki państwa, które gwarantują ochronę społeczeństwa i każdego obywatela przed zagrożeniami. Ustawodawca przyjmuje, że polityka państwa w zakresie bezpieczeństwa narodowego i obrony ma na celu zapewnienie bezpieczeństwa wojskowego, cywilnego, gospodarczego, informacyjnego, środowiska oraz cybernetycznego w Ukrainie oraz w zakresie prowadzonej polityki zagranicznej. Ustawa odnosi się również do przyjętej Strategii Cyberbezpieczeństwa Ukrainy.

Zgodnie z przyjętym w prezentowanym akcie normatywnym słowniczkiem pojęciowym, przez Strategię Bezpieczeństwa Cybernetycznego w Ukrainie rozumie się długoterminowy dokument planistyczny, który identyfikuje zagrożenia dla cyberbezpieczeństwa Ukrainy, priorytety i kierunki zabezpieczania cyberbezpieczeństwa Ukrainy w celu stworzenia warunków bezpiecznego funkcjonowania cyberprzestrzeni, jej wykorzystania w interesie jednostki, społeczeństwa i państwa. Prawodawca w rozdziale 5 ustawy, regulującym programy bezpieczeństwa narodowego, odnosi się do Strategii Cyberbezpieczeństwa Ukrainy jako aktu kierunkowego, stanowiącego podstawę do wydawania na jej podstawie i w granicach wyznaczonych jej przepisami aktów normatywnych regulujących obszar cyberprzestrzeni. Ustawa jasno określa organy państwa odpowiedzialne za przygotowywanie i zatwierdzanie Strategii Ceberbezpieczeństwa, wskazując Narodowe Centrum Koordynacji Cyberbezpieczeństwa (organ roboczy Rady Bezpieczeństwa Narodowego i Obrony Ukrainy) jako podmiot wyznaczony przez prezydenta Ukrainy do opracowania Strategii, która następnie podlega zatwierdzeniu przez prezydenta Ukrainy. Tak sformułowana delegacja ustawowa w sposób niebudzący wątpliwości wskazuje prezydenta Ukrainy jako organ odpowiedzialny za przygotowanie i realizację postanowień Strategii Cyberbezpieczeństwa Ukrainy, w sposób bezpośredni lub za pośrednictwem wyznaczonych organów. Aktualne regulacje prawne oraz udział prezydenta Ukrainy w kształtowaniu konstytucyjnych i ustawowych organów państwowych świadczy o wzmocnieniu pozycji ustrojowej głowy państwa w strukturze organów państwowych Ukrainy [Ławniczak 2011: 269]. 
Przedstawione w ujęciu chronologicznym akty normatywne regulujące sferę cyberprzestrzeni stanowią zespół podstawowych przepisów prawnych porządkujących obszar cybernetyczny Ukrainy oraz wskazują główne obszary cyberbezpieczeństwa. Aktualność podejmowanych działań prawotwórczych w zakresie cyberbezpieczeństwa stanowi o pilnej potrzebie uregulowania tej sfery życia społecznego w celu zapobieżenia zidentyfikowanym i wyróżnionym w Strategii Cyberbezpieczeństwa zagrożeniom zewnętrznym i wewnętrznym.

\section{ROLA I KOMPETENCJE PREZYDENTA UKRAINY W ZAKRESIE CYBERBEZPIECZEŃSTWA}

Zróżnicowanie zagrożeń w cyberprzestrzeni wymaga od państwa stworzenia zintegrowanego systemu organów państwowych odpowiedzialnych za wyznaczanie, koordynowanie i realizację polityki cyberbezpieczeństwa. Pozycja ustrojowa prezydenta oraz układ wzajemnie łączących relacji głowy państwa z innymi konstytucyjnymi organami państwa powinien gwarantować skuteczne reagowanie na zagrożenia i incydenty w zakresie bezpieczeństwa państwa, w tym w obszarze cyberprzestrzeni. Ustrojodawca w Konstytucji Ukrainy szczególną rolę w zakresie zapewnienia bezpieczeństwa państwowego wyznaczył prezydentowi Ukrainy. Należy stwierdzić, że prezydent, działając na podstawie przepisów Konstytucji, jest aktywnym uczestnikiem procesu formułowania przepisów regulujących bezpieczeństwo cybernetyczne.

Konstytucja Ukrainy w sposób szczególny określa miejsce prezydenta w systemie konstytucyjnych organów państwowych. Prezydent, zgodnie z art. 102, jest głową państwa i występuje w imieniu państwa. Jest również gwarantem suwerenności państwa, integralności terytorialnej Ukrainy, przestrzegania Konstytucji Ukrainy oraz praw i wolności człowieka i obywatela. Na prezydencie jako głowie państwa spoczywa, zgodnie z art. 17 Konstytucji, obowiązek zapewnienia bezpieczeństwa państwa i ochrony granic państwowych. Tak skonstruowane funkcje ustrojowe wyznaczają konstytucyjne uprawnienia prezydenta Ukrainy, określone w art. 106 Konstytucji. Prezydent jako gwarant suwerenności państwa i integralności terytorialnej wykonuje swoje obowiązki zarówno w czasie pokoju, jak i w stanach nadzwyczajnych, w ramach stosunków wewnętrznych i międzynarodowych, samodzielnie oraz, w przypadkach określonych w ustawach, wspólnie z wyznaczonymi organami państwowymi [Olechno 2009: 103].

W zakresie bezpieczeństwa, zgodnie z art. 106 Konstytucji, prezydent gwarantuje niepodległość państwa, bezpieczeństwo narodowe i prawną ciągłość państwa, jest Najwyższym Głównodowodzącym Sił Zbrojnych Ukrainy, powołuje i odwołuje naczelne dowództwo Sił Zbrojnych Ukrainy i innych formacji wojskowych oraz kieruje sprawami bezpieczeństwa narodowego i obrony państwa. Prezydent stoi również na czele Rady Bezpieczeństwa Narodowego i Obrony Ukrainy oraz przedkłada Radzie Najwyższej Ukrainy wnioski dotyczące powo- 
łania szefa Służby Bezpieczeństwa Ukrainy. Prezydent jako gwarant suwerenności integralności terytorialnej państwa jest również wyposażony w kompetencje przedkładania parlamentowi wniosku o ogłoszenie stanu wojny oraz podejmuje decyzję o powszechnej albo częściowej mobilizacji i wprowadzeniu stanu wojennego na terenie Ukrainy lub jej części. Wykazane uprawnienia prezydenta Ukrainy mogą dotyczyć spraw bezpieczeństwa państwa w zakresie przeciwdziałania zagrożeniom lub atakom cybernetycznym mogącym zagrażać bezpieczeństwu państwa i obywateli. W ocenie autora, uprawnieniem prezydenta, w ramach którego może skutecznie wpływać na kształt polityki bezpieczeństwa cyberprzestrzeni w Ukrainie, jest również możliwość zwracania się z orędziami do narodu oraz corocznymi i nadzwyczajnymi orędziami o stanie państwa do Rady Najwyższej Ukrainy. Prezydent w orędziach może prezentować założenia programowe aktów normatywnych dotyczących ochrony cyberprzestrzeni oraz przedstawiać zagrożenia związane z bezpieczeństwem cybernetycznym Ukrainy.

Rolą prezydenta Ukrainy w procesie kształtowania polityki cyberbezpieczeństwa Ukrainy jest wypełnienie uprawnień wynikających z Konstytucji Ukrainy i ustaw oraz współudział, jako aktywny uczestnik procesu legislacyjnego, w procesie tworzenia aktów prawnych regulujących materię cyberprzestrzeni. Rolę prezydenta Ukrainy wyznaczają również przepisy aktów normatywnych, które przyznają mu szerokie kompetencje w zakresie kształtowania bezpieczeństwa cybernetycznego Ukrainy. Pozycja ustrojowa prezydenta Ukrainy jako gwaranta suwerenności i niepodległości państwa oraz uczestnika procesu kształtowania polityki cyberbezpieczeństwa państwa oddziałuje również na sferę stosunków międzynarodowych. Prezydent Ukrainy przez pełnienie roli reprezentanta państwa sprawującego kierownictwo nad polityką zagraniczną oraz gwarantującego bezpieczeństwo narodowe ma bezpośredni wpływ nie tylko na sferę prawodawczą, ale również na kształt stosunków międzynarodowych. Zdefiniowanie w Strategii Cyberbezpieczeństwa zagrożeń zewnętrznych płynących z agresji Federacji Rosyjskiej przekłada się na prowadzoną przez Ukrainę politykę wobec Rosji.

Prezydent Ukrainy w celu wykonywania swoich konstytucyjnych uprawnień wydaje dekrety i rozporządzenia regulujące m.in. sprawy z zakresu cyberbezpieczeństwa państwa. Działając na podstawie art. 107 Konstytucji, wydał dekret zatwierdzający postanowienie Rady Bezpieczeństwa Narodowego i Obrony Ukrainy w sprawie Strategii Bezpieczeństwa Cybernetycznego Ukrainy ${ }^{1}$, tym samym inicjując proces zmian w zakresie cyberbezpieczeństwa Ukrainy. Prezydent jako przewodniczący Rady Bezpieczeństwa Narodowego i Obrony Ukrainy stał się bezpośrednim realizatorem postanowień Strategii w zakresie budowania

\footnotetext{
${ }^{1}$ Strategia Cyberberbezpieczeństwa Ukrainy bazuje na postanowieniach Konwencji o cyberprzestępstwach, ratyfikowanej ustawą z dnia 7 września 2005 r., ustawodawstwie ukraińskim regulującym bezpieczeństwo narodowe, zasady polityki wewnętrznej i zagranicznej, łączności elektronicznej, ochrony państwowych zasobów informacyjnych i informacji, zmierzającym do realizacji do 2020 r. Strategii Bezpieczeństwa Narodowego Ukrainy, zatwierdzonej dekretem prezydenta Ukrainy z dnia 26 maja 2015 r. Nr 287 o Strategii Bezpieczeństwa Narodowego Ukrainy.
} 
Krajowego Systemu Bezpieczeństwa Cybernetycznego. W celu usprawnienia prac Rady Bezpieczeństwa Narodowego i Obrony Ukrainy w zakresie realizacji działań związanych z kształtowaniem krajowego systemu cyberbezpieczeństwa prezydent Ukrainy, działając w granicach określonych w art. 107 Konstytucji i na podstawie postanowień Strategii Cyberbezpieczeństwa, wydał dekret zatwierdzający postanowienie Rady Bezpieczeństwa Narodowego i Obrony Ukrainy w zakresie powołania Narodowego Centrum Koordynacji Cyberbezpieczeństwa ${ }^{2}$.

Ustawa z 5 października 2017 r. o podstawowych zasadach zapewnienia bezpieczeństwa cybernetycznego Ukrainy wyznacza rolę i uszczegóławia kompetencje prezydenta Ukrainy w zakresie ochrony cyberprzestrzeni.

Po pierwsze, w art. 3 ustawy wymieniono akty prawne stanowiące podstawę zapewnienia bezpieczeństwa cybernetycznego w Ukrainie. Wśród nich ustawodawca wyróżnia te, które są wydawane przez prezydenta Ukrainy, a mianowicie dekrety prezydenta Ukrainy. Dodatkowo prezydent w ramach swoich kompetencji ma wpływ na kształtowanie innych przepisów prawnych wydawanych w formie ustaw przez aktywne uczestnictwo w procesie legislacyjnym.

Po drugie, art. 5 ustawy określa podmioty odpowiedzialne za bezpieczeństwo cybernetyczne w Ukrainie. Ustawa stwierdza, że prezydent Ukrainy odpowiada za koordynację działań w dziedzinie cyberbezpieczeństwa, będącego elementem bezpieczeństwa narodowego Ukrainy, a zadania te wykonuje za pośrednictwem Rady Bezpieczeństwa Narodowego i Obrony Ukrainy. Zgodnie z ust. 2 art. 5 ustawy, Narodowe Centrum Koordynacji Cyberbezpieczeństwa jako organ roboczy Rady Bezpieczeństwa Narodowego i Obrony Ukrainy odpowiedzialny za koordynacje i kontrolę działalności sektora bezpieczeństwa i obrony w celu zapewnienia cyberbezpieczeństwa przedstawia prezydentowi Ukrainy propozycje dotyczące tworzenia i rozwoju Strategii Cyberbezpieczeństwa Ukrainy. W ten sposób ustawodawca jeszcze raz podkreślił rolę prezydenta Ukrainy w formułowaniu nie tylko aktualnej polityki cyberbezpieczeństwa, ale również w możliwości kształtowania norm kierunkowych stanowiących podstawę systemu bezpieczeństwa cybernetycznego Ukrainy.

Po trzecie, ustawodawca w art. 15 ustawy przyjął podział środków kontroli nad zapewnieniem bezpieczeństwa cybernetycznego, wyróżniając kontrolę parlamentarną, bieżącą kontrolę systemu cyberbezpieczeństwa oraz kontrolę realizowaną przez niezależnych audytorów. Ustawa wyznacza prezydenta Ukrainy, w ramach przyznanych przez Konstytucję i ustawy kompetencji, do prowadzenia, wspólnie z Gabinetem Ministrów, bieżącej kontroli systemu bezpieczeństwa cy-

2 Narodowe Centrum Koordynacji Cyberbezpieczeństwa składa się z: dyrektora, sekretarza oraz innych członków Centrum. Dyrektor Centrum jest sekretarzem Narodowej Rady Bezpieczeństwa i Obrony Ukrainy. Z urzędu członkami Centrum są: Zastępca Ministra Obrony Ukrainy, Szef Sztabu Generalnego Sił Zbrojnych Ukrainy, Szef Służby Bezpieczeństwa Ukrainy, Szef Służby Wywiadu Zagranicznego Ukrainy, Szef Policji Narodowej Ukrainy, Szef Narodowego Banku Ukrainy (za zgodą) oraz Szef Wywiadu Obrony Ukrainy, Szef Państwowej Służby Granicznej Ukrainy, Szef Państwowych Służb Specjalnych Komunikacji i Ochrony Informacji Ukrainy. 
bernetycznego obejmującego podmioty sektora bezpieczeństwa i obrony Ukrainy. Kontrola parlamentarna podlega Radzie Najwyższej Ukrainy i obejmuje kontrolę przestrzegania ustawodawstwa w zakresie wdrażania środków i rozwiązań prawnych w celu zapewnienia ochrony cyberprzestrzeni. W ramach trzeciej formy kontroli dokonywanej w formie audytów prezydent, wspólnie z Gabinetem Ministrów i Radą Najwyższą Ukrainy, otrzymuje raport z przeprowadzonego badania audytowego. Należy ocenić, że procedura przekazywania audytów ma na celu zapoznanie prezydenta $\mathrm{z}$ aktualnym stanem wdrażania i realizacji postanowień aktów prawnych regulujących materię cyberprzestrzeni.

Ustawa z 21 czerwca 2018 r. o bezpieczeństwie narodowym Ukrainy potwierdza sprawowanie przez prezydenta Ukrainy, na podstawie art. 106 i 107 Konstytucji Ukrainy, kontroli nad sektorem bezpieczeństwa i obrony państwa. Ustawa stwierdza, że działania te prezydent podejmuje bezpośrednio, jak również przez Radę Bezpieczeństwa Narodowego i Obrony Ukrainy, której przewodniczy, i inne organy oraz służby pomocnicze. Ustawa enumeratywnie wyszczególnia kompetencje prezydenta Ukrainy, który sprawuje kierownictwo w sferze bezpieczeństwa narodowego i obrony [Baluk 2007: 125]. Ustawodawca, wyszczególniając kompetencje Prezydenta w zakresie bezpieczeństwa narodowego i obrony, dokonał powtórzenia uprawnień głowy państwa określonych w art. 106 i 107 Konstytucji Ukrainy.

$\mathrm{W}$ ramach funkcji ustrojowych prezydent jako głowa państwa wypełnia obowiązki związane z prowadzeniem polityki zagranicznej, również w zakresie zapewnienia bezpieczeństwa narodowego [Tacij 2011: 694]. Zgodnie z art. 24 ustawy o bezpieczeństwie narodowym, współpraca międzynarodowa na rzecz bezpieczeństwa narodowego jest jedną z form realizacji polityki państwa $\mathrm{w}$ dziedzinie bezpieczeństwa narodowego i ma na celu ochronę interesów narodowych Ukrainy. Ogólne kierownictwo nad realizacją współpracy międzynarodowej w sprawach bezpieczeństwa narodowego sprawuje prezydent Ukrainy. Należy przyjąć, że w zakresie współpracy międzynarodowej dotyczącej polityki bezpieczeństwa państwa prezydent Ukrainy ma dwojakie uprawnienia. Po pierwsze, pełni funkcję reprezentanta państwa w stosunkach międzynarodowych, sprawuje kierownictwo nad polityką zagraniczną, podejmuje decyzję o uznaniu państw obcych. Po drugie, Konstytucja przyznaje prezydentowi Ukrainy uprawnienia do zawierania umów międzynarodowych samodzielnie lub, zgodnie $\mathrm{z}$ art. 9 ustawy z dnia 20 lipca 2014 r. o umowach międzynarodowych Ukrainy (Zakon Ukraijny pro Miżnarodni Dohowory Ukraijiny, BBP, 2004, Nr 50, poz. 540), w przypadkach związanych między innymi z zawiązaniem lub przystąpieniem przez Ukrainę do organów lub organizacji międzynarodowych dotyczących wspólnych systemów bezpieczeństwa, do podpisywania ustaw przyjętych przez Radę Najwyższą w sprawie wyrażenia zgody na ratyfikację umowy międzynarodowej.

Przeprowadzona przez autora analiza prawna aktów normatywnych regulujących obszar cyberbezpieczeństwa ukazuje rolę prezydenta Ukrainy i szeroki zakres jego kompetencji przyznanych mu przez ustawodawcę. Głowa państwa staje się głównym organem państwa odpowiedzialnym za koordynację polityki 
państwa w zakresie ochrony cyberprzestrzeni. Dokonana analiza prawna pozwala również na stwierdzenie, że rola prezydenta Ukrainy w zakresie zapewnienia bezpieczeństwa cybernetycznego dotyczy zarówno polityki wewnętrznej państwa, jak i sfery stosunków międzynarodowych.

Na podstawie przepisów Konstytucji Ukrainy oraz aktów prawnych regulujących materię cyberprzestrzeni możemy również wskazać dodatkowe uprawnienia prezydenta Ukrainy w zakresie ochrony cyberprzestrzeni. Po pierwsze, są związane z działalnością kreacyjną prezydenta w zakresie formowania składu Rady Bezpieczeństwa Narodowego i Obrony Ukrainy oraz innych organów i służb pomocniczych. Zgodnie z art. 107. Konstytucji Ukrainy, prezydent jest przewodniczącym Rady oraz kreuje skład organu kolegialnego ${ }^{3}$. Prezydent Ukrainy, działając na podstawie art. 106 pkt. 28, tworzy konsultacyjne, doradcze i inne pomocnicze organy i służby dla wypełnienia swoich funkcji. Jednym z organów mających charakter pomocnicy jest Narodowe Centrum Koordynacji Cyberbezpieczeństwa, powołane mocą dekretu prezydenta Ukrainy z dnia 7 czerwca 2016 r. Organ ten strukturalnie podlega Radzie Bezpieczeństwa Narodowego i Obrony Ukrainy. W ramach działalności kreacyjnej prezydent Ukrainy ma również wpływ na kształt Gabinetu Ministrów jako najwyższego organu w systemie organów władzy wykonawczej Ukrainy, odpowiedzialnego między innymi za realizację bieżącej polityki związanej z ochroną bezpieczeństwa narodowego. Prezydent Ukrainy, działając na podstawie art. 106 pkt. 10, przedkłada Radzie Najwyższej Ukrainy wnioski dotyczące powołania ministra obrony Ukrainy oraz ministra spraw zagranicznych Ukrainy. Partycypacja prezydenta Ukrainy w formowaniu składu Gabinetu Ministrów podkreśla rolę ustrojową prezydenta $\mathrm{w}$ zakresie kształtowania polityki bezpieczeństwa narodowego i spraw zagranicznych Ukrainy.

Konstytucja Ukrainy wyposaża prezydenta również w środki prawne z zakresu prawotwórstwa. Podstawowymi aktami prawnymi wydawanymi przez prezydenta są dekrety i rozporządzenia, publikowane na podstawie i w celu wykonania Konstytucji oraz ustaw Ukrainy. Prezydent jako organ odpowiedzialny za koordynację polityki bezpieczeństwa cybernetycznego, w ramach przyznanych mu uprawnień, wydał dwa dekrety regulujące obszar cyberprzestrzeni: z dnia 15 marca 2016 r. o Strategii Bezpieczeństwa Cybernetycznego Ukrainy oraz z dnia 7 czerwca 2016 r. o utworzeniu Narodowego Centrum Koordynacji Cyberbezpieczeństwa. Prezydent Ukrainy jako jedyny konstytucyjny organ ma prawo do wydawania aktów prawnych w formie dekretów zatwierdzających postanowienia Rady Bezpieczeństwa Narodowego i Obrony Ukrainy [Mojak 2002: 276]. Warto również wskazać, że ustawa zasadnicza gwarantuje prezydentowi Ukrainy środki prawne pozwalające na aktywne uczestnictwo w procesie ustawodawczym, zarówno na poziomie inspirującym dzięki prawu inicjatywy ustawodawczej, jak

3 W skład Rady Bezpieczeństwa Narodowego i Obrony Ukrainy z urzędu wchodzą: Premier Ukrainy, Minister Obrony Ukrainy, Szef Służby Bezpieczeństwa Ukrainy, Minister Spraw Wewnętrznych Ukrainy oraz Minister Spraw Zagranicznych Ukrainy. 
i kontrolnym dzięki prawu stosowania weta prezydenckiego [zob. Federenko 2016; Sowhyrja i Szkulina 2018; Golebiowski 2018]. Tym samym prezydent Ukrainy staje się aktywnym uczestnikiem procesu legislacyjnego, w wyniku którego w życie wchodzą nowe regulacje prawne obejmujące swoim zakresem materię cyberprzestrzeni i jej zabezpieczenia przez państwo.

\section{KONKLUZJE}

Należy przyjąć, że system bezpieczeństwa narodowego tworzą podmioty, środki i zasoby, które zostały wyznaczone przez państwo do realizacji różnorodnych zadań w dziedzinie bezpieczeństwa. Analizując zespół regulacji prawnych dotyczących ochrony cyberprzestrzeni Ukrainy, należy uznać, że w latach 2016-2018 przyjęto zespół podstawowych aktów prawnych dotyczących cyberbezpieczeństwa. Przepisy prawne określają podmioty, środki prawne i zasoby organizacyjne wyznaczone do ochrony cyberprzestrzeni. Regulacje prawne przyznają szczególną i silną pozycję prezydentowi Ukrainy jako organowi odpowiedzialnemu za koordynację polityki zapewnienia cyberbezpieczeństwa w Ukrainie. Ocenia się, że rolą prezydenta jest inspirowanie, kształtowanie i realizacja działań związanych z ochroną cyberprzestrzeni. Uprawnienia prezydenta rozszerzono w wiele narzędzi prawnych pozwalających na wypełnianie postanowień Strategii Cyberbezpieczeństwa. Kompetencje głowy państwa w zakresie cyberbezpieczeństwa wynikają nie tylko z aktów normatywnych regulujących ten obszar, lecz także pośrednio z funkcji ustrojowych i konstytucyjnie zagwarantowanych kompetencji prezydenta Ukrainy.

Ustawodawstwo ukraińskie definiuje pojęcie cyberbezpieczeństwa jako ochronę życiowych interesów człowieka i obywatela, społeczeństwa i państwa podczas korzystania z cyberprzestrzeni, zapewniającą zrównoważony rozwój społeczeństwa informacyjnego i cyfrowego środowiska komunikacyjnego oraz szybkie wykrywanie, zapobieganie i neutralizację rzeczywistych i potencjalnych zagrożeń dla bezpieczeństwa narodowego Ukrainy w cyberprzestrzeni. Strategia Cyberbezpieczeństwa Ukrainy identyfikuje najważniejsze zagrożenia zewnętrzne i wewnętrzne związane z cyberprzestrzenią. Jednym z zidentyfikowanych w Strategii wyzwań dla Ukrainy oraz prezydenta jako organu koordynującego politykę cyberbezpieczeństwa jest implementacja na grunt prawa ukraińskiego rozwiązań prawnych dotyczących cyberprzestrzeni z zachowaniem standardów UE i NATO. Pilną potrzebą jest również jak najszybsze zabezpieczenie infrastruktury krytycznej przed potencjalnymi atakami i incydentami cybernetycznymi.

$\mathrm{W}$ ocenie autora, dynamizm wprowadzania regulacji prawnych dotyczących omawianego tematu wynika z zagrożeń zewnętrznych związanych $\mathrm{z}$ agresją Federacji Rosyjskiej i wypełnianiem zobowiązań Ukrainy wobec Sojuszu Północnoatlantyckiego, co odzwierciedlają postanowienia Strategii Cyberbezpieczeństwa Ukrainy. Warto zwrócić uwagę, że dotychczasowy brak regulacji 
prawnych obejmujących swoim zakresem cyberprzestrzeń w państwie, które od czterech lat prowadzi akcję zbrojną, powodowało słabość systemu ochrony cyberprzestrzeni, a brak wyznaczenia organów odpowiedzialnych za jej ochronę i procedur mających na celu zapobieganie atakom i incydentom cybernetycznym zagrażało bezpieczeństwu narodowemu Ukrainy i ochronie obywateli państwa. Krótki okres obowiązywania ustaw regulujących materię cyberprzestrzeni (ustawa o cyberprzestrzeni weszła w życie w maju 2018 r., ustawa o bezpieczeństwie narodowym w czerwcu 2018 r.) nie pozwala na ostateczne stwierdzenie i ocenę ich efektywności w zakresie stosowania przepisów przez uprawnione organy państwowe. Władze Ukrainy dzięki wprowadzeniu regulacji prawnych dotyczących cyberbezpieczeństwa wykonały pierwszy krok w procesie stworzenia krajowego systemu ochrony cyberprzestrzeni. Biorąc pod uwagę centralizację uprawnień dotyczących prowadzenia bieżącej polityki zapewnienia cyberbezpieczeństwa w rękach prezydenta Ukrainy i podległych mu organów, Rada Najwyższa Ukrainy powinna w sposób szczególny wypełniać funkcję ustawodawczą i kontrolną w zakresie przewidzianym Konstytucją Ukrainy, w celu zapewnienia wzajemnego hamowania się władz i niedopuszczenia do sytuacji uzurpacji władzy przez prezydenta Ukrainy.

Title: The Role and Competence of the President of Ukraine in Terms of Shaping the Legal Regime of Cyberspace Protection. Theoretical and Legal Analysis of Legal Regulations in the Field of Cybersecurity of Ukraine

Summary: The subject of the article oscillates around issues related to the shaping of legal regulations regarding cybersecurity of Ukraine. The article presents a theoretical analysis of legal acts, in particular, the Constitution of Ukraine of June 26, 1996, and acts and decrees of the President of Ukraine regulating the protection of the area of Ukrainian cyberspace. The author also presents the role of the President of Ukraine in terms of formulating the cybersecurity policy, specifying the constitutional and statutory competencies of the President of Ukraine regarding the protection of cyberspace.

Keywords: Ukraine, legal system, Ukrainian law, president of Ukraine, Constitution of Ukraine, cyberlaw, cybersecurity

\section{BIBLIOGRAFIA}

1. Baluk W. (2007), Ukraina, [w:] Ustroje polityczne krajów Wspólnoty Niepodległych Państw, W. Baluk, A. Czajkowski (red.), Wrocław.

2. Fedorenko W.L. (2016), Konstytucijne Prawo Ukrajiny, Kyjiw.

3. Golebiowski M. (2018), The powers of the presidents of Ukraine and the Republic of Poland in the sphere of lawmaking process: a comparative and legal analysis, "The Scientific Papers of the Legislation Institute of the Verkhovna Rada of Ukraine", nr 3.

4. Konstytucija Ukrajini. (1996), Widomosti Werhownoji Rady Ukrajiny (BBP), nr 30, poz. 141. 
5. Leszczyński P.A. (2014), Bezpieczeństwo narodowe Ukrainy w kontekście jej podstaw konstytucyjnych i położenia geopolitycznego - węzłowe zagadnienia, „Zeszyty Naukowe Uniwersytetu Przyrodniczo-Humanistycznego w Siedlcach, Seria Administracja i Zarządzanie", nr 103.

6. Ławniczak A. (2011), Monarchiczne i republikańskie głowy państwa w Europie, Wrocław.

7. Mojak R. (2002), Republika Ukrainy, [w:] Ustroje państw współczesnych 2, E. Gdulewicz (red.), Lublin.

8. Olechno A. (2009), Instytucja Prezydenta w systemie konstytucyjnych organów Ukrainy (19962005), Toruń.

9. Piskorska H. (2009), Informatyzacja Ukrainy i problemy integracji z europejskim i globalnym społeczeństwem informacyjnym w kontekście bezpieczeństwa informacyjnego, [w:] Polityka bezpieczeństwa narodowego państw obszaru WNP. Wybrane problemy, W. Baluk (red.), Toruń.

10. Raport "Cybercrime and cybersecurity strategies in the Eastern Partnership region", Cybercrime@EAP, EU/Council of Europe Eastern Partnership Facility, Bucharest 2015 (https:// rm.coe.int/16803053d2).

11. Semeniy J., Glushchenko S., Makarevich O. 2018, Ukraine, [w:] Cybersecurity 2018, B.A. Powell, J.C. Chipman (red.), Law Business Research, London.

12. Sowhyrja O.W., Szuklina N.G. (2018), Konstytucijne Prawo Ukrajini, Pownyji Kurs, Kyjiw.

13. Stec A. (2014), Pozycja ustrojowa Prezydenta w systemie konstytucyjnym Ukrainy (1991-2012), Lwów.

14. Tacij W. Ja. (red.), (2011), Konstytucija Ukraiini. Naukowo-praktycznyj Komentar, Charkiw.

15. Tymkiv Y. (2009), Mechanizmy wspótpracy i instytucjonalizacja stosunków Ukraina-UE, [w:] Polityka bezpieczeństwa narodowego państw obszaru WNP. Wybrane problemy, W. Baluk (red.), Toruń.

16. Zakon Ukraijny pro Miżnarodni Dohowory Ukraijiny Widomosti Werhownoji Rady Ukrajiny (BBP), 2004, Nr 50, poz. 540.

17. Zakon Ukrajiny pro Ratyfikaciju Konwencjii pro Kiberzloczynnisti Widomosti Werhownoji Rady Ukrajiny (BBP), 2006, Nr 5-6, poz. 71.

18. Zakon Ukraijny pro osnowni zasady zabezpeczennja kiberbezpeczennja kiberbezpeky, Widomosti Werhownoji Rady Ukrajiny (BBP), 2017, Nr 45, poz. 403.

19. Zakon Ukraijny pro nacjonalny bezpeky Ukraijiny, Oficijinyj Wisnyk Ukraijiny, 018 r., Nr 55, stor. 51, poz. 1903, kod akta 90815/2018.

20. Ukaz Prezydenta Ukraijny pro riszennja Rady Nacionalnoii Bezpeky i oborony Ukraiiny od 27 sicznja 2016 roku „Pro Stratehiju Kiberbezpeky Ukraijny”.

21. Ukaz Prezydenta Ukraijny Nr 242/2016 pro Nacjonalnyii Koordynaciiinyj Centr Kiberbezpeky. 